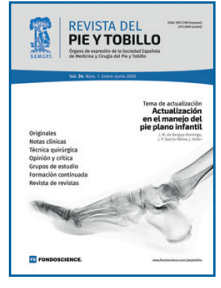

\title{
Editorial
}

\section{Editorial del presidente de la SEMCPT}

\section{SEMCPT president's editorial}

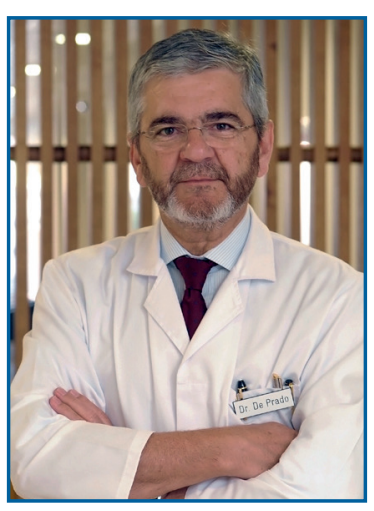

Dr. Mariano de Prado Presidente de la SEMCPT
Apreciados amigos y lectores:

Sin la menor duda, estamos viviendo el momento más difícil e incierto del presente siglo como consecuencia de la pandemia declarada por la aparición del virus COVID-19, que nos afecta de manera muy especial a los profesionales sanitarios. Antes de nada, deseo sinceramente que tanto vosotros como vuestras familias os encontréis bien.

Siguiendo las indicaciones dictadas por el Ministerio de Sanidad, Consumo y Bienestar Social, que prohíben toda actividad que exija compartir espacios físicos a sus participantes y anteponiendo la protección de la salud de nuestros asociados a la voluntad de compartir y transmitir los conocimientos de nuestra especialidad, la SEMCPT se ha visto obligada a aplazar todas nuestras actividades de formación programadas para este año, tales como el Curso de Artroscopia de Pie y Tobillo, Curso Básico de Cirugía en Cadáver de Antepié y el I Curso de Ecografía en Tobillo y Pie, así como nuestro 42 Congreso Nacional, que este año iba a tener lugar en Alicante.

Con el fin de paliar parcialmente las consecuencias de estos aplazamientos, desde la Junta Directiva de la SEMCPT hemos programado diferentes actividades científicas que se van a realizar de manera telemática, entre las que quiero destacar el I Congreso Online de la SEMCPT, que se celebrará los días 12 y 13 de junio de 2020, y los webinar de Formación en Pie y Tobillo, que se programarán mensualmente.

Como es lógico, el área editorial de nuestra sociedad no se ha visto afectada por ningún tipo de prohibición durante esta pandemia y continúa, por tanto, 
siendo un pilar básico para la difusión científica de nuestra especialidad; por ello, os invito y animo a que continuéis, si cabe con mayor intensidad, participando en la elaboración de nuestra Revista del Pie y Tobillo enviándonos originales, notas clínicas y/o técnicas quirúrgicas para su publicación. Igualmente, quiero comunicaros que, en las próximas semanas, verá la luz la monografía de este año, titulada Cirugía de preservación de la articulación del tobillo, y que llegará a todos los miembros de nuestra sociedad durante la celebración del I Congreso Online anteriormente comentado.

Deseo finalizar este editorial expresando mi reconocimiento al Dr. Mario Herrera, director de la Revista de Pie y Tobillo y responsable del área editorial, por su esfuerzo y dedicación incansable, sin los cuales no sería posible editar los dos números anuales de la revista y la monografía; así como deseando que pase tan pronto como sea posible esta terrible pandemia, que tan bruscamente nos ha obligado a modificar nuestros hábitos y maneras de relacionarnos socialmente durante los últimos meses, de modo que podamos retomar el programa científico de nuestra sociedad tal y como estaba programado inicialmente.

Mariano de Prado Serrano

Presidente de la SEMCPT 